\title{
TTR
}

Traduction, terminologie, re?daction

\section{Mark Shuttleworth with Moira Cowie. Dictionary of Translation Studies. Manchester, St. Jerome Publishing, 1997.}

\section{Marilyn Gaddis Rose}

Volume 10, numéro 1, 1er semestre 1997

Langues, traduction et post-colonialisme

Languages, Translation and Post-Colonialism

URI : https://id.erudit.org/iderudit/037291ar

DOI : https://doi.org/10.7202/037291ar

Aller au sommaire du numéro

Éditeur(s)

Association canadienne de traductologie

ISSN

0835-8443 (imprimé)

1708-2188 (numérique)

Découvrir la revue

Citer ce compte rendu

Rose, M. G. (1997). Compte rendu de [Mark Shuttleworth with Moira Cowie. Dictionary of Translation Studies. Manchester, St. Jerome Publishing, 1997.]

TTR, 10(1), 310-312. https://doi.org/10.7202/037291ar

Tous droits réservés (C) TTR: traduction, terminologie, rédaction — Les auteurs, 1997
Ce document est protégé par la loi sur le droit d'auteur. L'utilisation des services d'Érudit (y compris la reproduction) est assujettie à sa politique d'utilisation que vous pouvez consulter en ligne.

https://apropos.erudit.org/fr/usagers/politique-dutilisation/ 


\section{Mark Shuttleworth with Moira Cowie. Dictionary of Translation Studies. Manchester, St. Jerome Publishing, 1997.}

This attractive reference work will prove useful, especially for those beginning either to teach or pursue translation studies. Moreover, scholars long in the field will find its selections and definitions a good touchstone. Such an undertaking has its risks, and we should be thankful that Shuttleworth was willing to take them. It also has its empowering rewards. (Cowie's role is not clear; she is the ninth person acknowledged on the next to last page of the introduction.)

Bearing on both the risks and rewards are the on-again/off-again reading habits of dictionary users. Although many of us read around the word we look up, generally we consult dictionaries; we do not read them. For example, as a reviewer, I forced myself to look at each Shuttleworth page, I read entries that I thought might be controversial or eccentric (or bore on my own work). Most users will read only the term(s) of interest of their project and only when or if their project requires it. And hardly anyone besides another lexicographer reads the introduction to a dictionary.

Shuttleworth's introduction, however, forestalls much criticism. He sets out to focus on terms that have been coined or re-defined in Western translation studies over, roughly, the past 50 years, i.e., starting with Eugene A. Nida. He states from the outset that he will pay less attention to terms dragooned from contributing disciplines like linguistics and comparative literature. We should bear in mind at all times that Shuttleworth's $41^{\text {st }}$ and $42^{\text {sd }}$ words in the Dictionary Introduction are "Great Britain". He is giving us his perspective from the University of Leeds. The inferences a user would make about translation studies in the U.S, and Canada would be quite skewed ${ }^{\text {. }}$

As to the risks that come with an enterprise like this, three are inevitable. First, a lexicographer has to be arbitrary. Second, such an

' TTR readers will find only Jean-Paul Vinay, Jean Darbelnet, and Roda Roberts. 
arbitrariness gives a misleadingly clear picture of the field. Third, its bibliography will be superseded by the time the book is published. Shuttleworth adroitly minimizes the risk of origin. He rarely ascribes invention but cites demonstrated use instead (e.g., "dynamic equivalence" "a term introduced by Nida", p. 47; "polysystem theory", "proposed by Even-Zohar", p. 127). In his place, I would not have had a Further Reading after each entry. Apparently, these lists contain the references easily available in the U.K., but that very criterion introduces a polemical factor and limits the marketability of the dictionary.

In some respects the rewards are a corollary. No matter how modest and diffident individual lexicographers may be, their work is legislative and empowering. Anyone coming into translation studies will assume that these selections are accepted and standard terms. I demur in no way whatsoever with any of Shuttleworth's definitions, but some of his selections amaze me. And some of his omissions as well. Let us take just one example.

Abusive Translation (pp. 1-2). It happens that I presided at the session of the SUNY - Binghamton University conference on "Differance in Translation" (October 1980) when Philip Lewis used this expression. The conference featured Jacques Derrida and the first U.S. airing of "Des tours de Babel". Lewis used the term provocatively and inclusively. Overall, he meant translation rhetoric that nuns counter to the U.S. trade book criterion that a translation should read as if written in the target language. His term covers a wide range of practices from those that make a text's foreign origin visible to those that wrench a text to fit the translator's ideology.

At the conference Lewis's role was prepare the audience for what is now seen as one of the major essays of the 80s. It was a conference that brought into question the nature of meaning and the capacity of words to convey it. (In translation studies I would defer to Lewis's wife, the distinguished scholarly translator Catherine Porter). As expressions go, many finer-tuned ones have replaced this one. Lawrence Venuti's "foreignized" (as well as my own "neo-literal") designates practices that forego target-language smoothness ("domesticated") and, if necessary, calque syntax and employ cognates. The result can be quite Benjaminian. The translating practices advocated by feminist translation theorists and 
postcolonial translation theorists additionally may wrench, even alter, a text. Such practices are represented also more neutrally by the spectrum of stances a translator, especially of literary and persuasive material may take vis-à-vis a text (e.g., with the author, against the author, with a character etc.) Although Shuttleworth has six entries under Culture (Cultural Approach, Cultural Borrowing, Cultural Substitution, Cultural Translation, Cultural Transplantation, Cultural Transposition), none really covers feminist or postcolonial translation for which there are no entries.

These comments do not mean that this Dictionary is flawed. They merely point out the entailments of lexicography. Prospective users who go to the authors in the bibliography will ultimately have a fuller picture of this changing discipline. Undoubtedly, in retrospect, they will be glad they consulted this Dictionary.

Marilyn Gaddis Rose

State University of New York at Binghamton 